\title{
MÔ PHỎNG NƯỚC DÂNG DỊ THƯờNG TRONG ĐợT TRIỀU CƯỜNG THÁNG 12 NĂM 2016 TẠI TUY HÒA-PHÚ YÊN BẰG MÔ HİNH SỐ TRI
}

\author{
Nguyễn Bá Thủy ${ }^{1}$
}

Tóm tắt: Trong nghiên cưu này, hiện tượng mưc nước biển dâng cao bất thuờng trong đợt triều cường vào tháng 12 năm 2016 được mô phỏng bằng mô hình tích hợp SuWAT nhằm muc đích xác định các hiệu ứng gây nước dâng dị thuờng tại khu vục. Trong đó, mô hình SuWAT tính toán nước dâng gây bởi ưng suất gió và ưng suất bức xạ sóng. Trương gió và các tác động trong khí quyển được mô phỏng tái phân tích bằng mô hình WRF. Kết quả cho thấy, mô hình SuWAT mô phỏng khá tốt về diễn biến của nước dâng trong đợt triều cuờng này, tuy nhiên kết quả còn thiên thấp so với thực tế. Nước dâng do úng suất sóng chiếm khoảng 32\% mục nước dâng tổng cộng tính toán.

Từ khóa: Nước dâng dị thường, ưng suất gió, nước dâng do sóng, Tuy Hòa.

Ban Biên tập nhận bài: 08/02/2019 Ngày phản biện xong: 20/04/2019 Ngày đăng bài: 25/05/2019

\section{Mở đầu}

Trong nghiên cứu này, thuật ngữ nước dâng dị thường được hiểu là hiện tượng mực nước biển dâng cao trên nền thủy triều nhưng không phải do bão hay áp thấp nhiệt đới. Tại ven biển miền Trung Việt Nam cứ vào các tháng cuối và đầu của năm sẽ có một số ngày xuất hiện mực nước biển dâng cao bất thường (dân gian hay gọi là triều cường), trong đó Tuy Hòa-Phú Yên là nơi có tần xuất xuất hiện nhiều nhất. Ngoài thủy triều thì trong các dao động nước lớn đó có phần đóng góp đáng kể của nước dâng do tác nhân khí tượng (gió, khí áp). Đây là lý do giải thích không phải trong tất cả những ngày có thủy triều cao mực nước tại khu vực này đều cao bất thường mà chỉ một vài ngày trong số đó. Khi mực nước dâng dị thường xuất hiện trùng với thời điểm triều thiên văn cao, kết hợp với sóng lớn sẽ gây ngập lụt, xói lở vùng bờ và ảnh hưởng tiêu cực tới các hoạt độngtại khu vực ven bờ biển.

Nghiên cứu về nước dâng do bão, áp thấp nhiệt đới đã được tiến hành từ rất lâu do thiệt hại gây bởi nước dâng trong bão rất lớn. Chính vì vậy, nhiều công nghệ dự báo nước dâng do bão

${ }^{1}$ Trung tâm Dự báo khí tượng thủy văn quốc gia Email:thuybanguyen@gmail.com đã được xây dựng để phục vụ dự báo, cảnh báo. Qua đó, nhiều mô hình thương mại (Delft3D, Mike2D, SMS...) cũng như mã nguồn mở (ROMS, POM....) được ứng dụng để phục vụ dự báo, cảnh báo. Ngoài hiện tượng nước dâng do bão và áp thấp nhiệt đới, tại nhiều khu vực trên thế giới khi gió có vận tốc lớn, thổi theo hướng ổn định và kéo dài cũng gây nước dâng đáng kể tại vùng ven bờ. Chính vì vậy, nước dâng do gió mùa gần đây đã được tập chung nghiên cứu và xây dựng công nghệ dự báo, nhất là tại những khu vực có địa hình trên bờ trũng và biên độ thủy triều lớn, chỉ cần xuất hiện nước dâng cỡ vài chục centimet vào kỳ triều cường có thể gây ngập trên diện rộng. Nước dâng gây bởi gió được tạo bởi theo 3 cơ chế: Tác động trực tiếp từ ứng suất gió trên bề mặt biển; tác động gián tiếp qua ứng suất sóng; và hiệu ứng bơm Ekman đẩy mực nước ven bờ dâng cao do dòng chảy dọc bờ. Tuy nhiên, từ số liệu quan trắc thực tế, việc xác định mức độ đóng góp của nước dâng do hiệu ứng nào gây nên là rất khó. Chúng ta chỉ có thể xác định nước dâng gây ra bởi các hiệu ứng riêng rẽ thông qua kết quả mô phỏng bằng mô hình số trị. Nước dâng do tác động trực tiếp từ ứng suất gió thường lớn trong trường hợp gió mạnh trong bão, áp thấp nhiệt đới, cơ chế gây nước dâng này đã 
được nghiên cứu nhiều. Với nước dâng do sóng, nhiều nghiên cứu đã khẳng định nước dâng gây bởi ứng suất sóng trong bão trong một số trường hợp có thể chiếm tới $35 \%$ mực nước dâng tổng cộng [6-8]. Rất nhiều nghiên cứu cũng đã khẳng định nước dâng do ứng suất sóng cao thường ở tại các khu vực ven bờ có độ dốc lớn [6-8]. Chính vì vậy, tại nhiều khu vực ven biển với độ dốc địa hình lớn và hướng gió thịnh hành vuông góc với đường bờ nước dâng trong các đợt gió mùa có thể cao tới 1 mét $[5,8]$.

Qua phân tích số liệu quan trắc nhiều năm tại trạm thủy văn Phú Lâm và trạm nghiệm triều tại cửa biển Tuy Hòa-Phú Yên tháng 12 năm 2016, nhóm tác giả Trần Hồng Thái và nnk [2] đã khẳng định có hiện tượng mực nước biển dâng cao dị thường trên nền thủy triều trong các đợt triều cường cao tại khu vực mà báo chí đã phản ánh trước đó và độ lớn của nước dâng dị thường có thể dao động từ 0,5-1,0 m. Kết quả thống kê các hình thế thời tiết (trường gió và khí áp) trong các đợt triều cường cao tại Tuy Hòa-Phú Yên, nhóm tác giả Nguyễn Bá Thủy và Trần Quang Tiến đã phát hiện nước dâng dị thường tại đây có mối liên hệ với hình thế thời tiết kết hợp giữa gió mùa Đông Bắc dọc ven biển Trung Bộ và đồng thời tồn tại một vùng thấp ngoài khơi khu vực giữa và nam Biển Đông có hướng di chuyển vào ven biển Việt Nam [4].

Tiếp theo 2 nghiên cứu về hiện tượng nước dâng dị thường tại Tuy Hòa-Phú Yên ở trên, trong nghiên cứu này, 2 đợt nước dâng dị thường tại Tuy Hòa-Phú Yên trong tháng 12 năm 2016 được mô phỏng bằng mô hình số trị nhằm xác định các hiệu ứng gây nước dâng. Mô hình số trị tích hợp SuWAT được áp dụng để đánh giá nước dâng do ứng suất gió và ứng suất sóng. Kết quả của nghiên cứu sẽ là cơ sở đề xuất công nghệ vàphương án dự báo nghiệp vụ nước dâng dị thường tại khu vực.

\section{Số liệu và phương pháp nghiên cứu}

a) Hiện tượng mưc nước biển dâng dị thuờng trong đợt triều cường tháng 12 năm 2016

Trong thời gian từ 15 tháng 10 năm 2016 đến 14 tháng 1 năm 2017, đề tài nghiên cứu khoa học cấp Nhà nước "Nghiên cưu nguyên nhân và xây dựng quy trình công nghệ cảnh báo, dụ báo hiện tuợng mưc nước biển dâng dị thường tại miền Trung và Nam Bộ Việt Nam" đã tiến hành quan trắc mực nước tại cửa biển Tuy Hòa với mục đích ghi nhận được nước dâng dị thường trong các tháng cuối năm 2016 và đầu năm 2017, đây là khoảng thời gian trong năm thường xuất hiện nước dâng dị thường tại khu vực mà các phương tiện truyền thông và người dân phản ánh. Vị trí trạm nghiệm triều được lựa chọn nằm ngay sát cửa biển Đà Rằng nên hầu như không bị ảnh hưởng của lũ trên sông $\mathrm{Ba}$. Trong thời gian quan trắc đã ghi nhận 2 đợt triều cường cao tại khu vực và cả 2 đợt triều cường này đều được phương tiện truyền thông phản ánh do bởi gây thiệt hại tại một số khu vực thuộc ven bờ biển Tuy Hòa [9]. Trên hình 1a-b là tác động của đợt triều cường vào đêm ngày 16 tháng 12 năm 2016 tại Tuy Hòa-Phú Yên. Kết quả phân tích loại thủy triều khỏi mực nước quan trắc trên hình 2 cho thấy trong tháng này có 2 đợt nước dâng cao và đỉnh nước dâng vào khoảng 1 giờ ngày 14 tháng $12(0,59 \mathrm{~m})$ và 23 giờ ngày 16 tháng 12 $(0,61 \mathrm{~m})$. Kết quả điều tra khảo sát thực địa và thu thập nước dâng sau đợt triều cường này cho thấy nước dâng dị thường chỉ xuất hiện cục bộ tại ven biển Tuy Hòa-Phú Yên, số liệu quan trắc mực nước tại trạm hải văn Quy Nhơn (cách Tuy Hòa khoảng $100 \mathrm{~km}$ về phía bắc) và Nha Trang (cách Tuy Hòa khoảng $80 \mathrm{~km}$ về phía nam) đã không ghi nhận nước dâng dị thường [2]. 


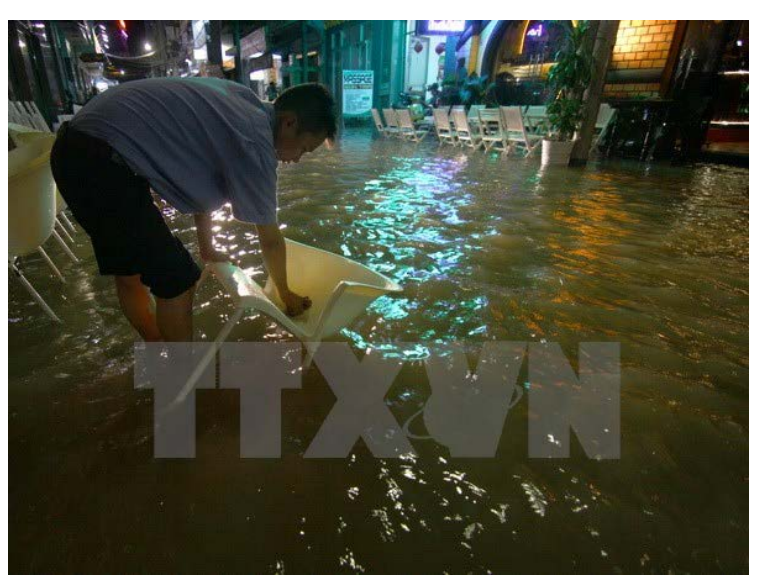

(a)

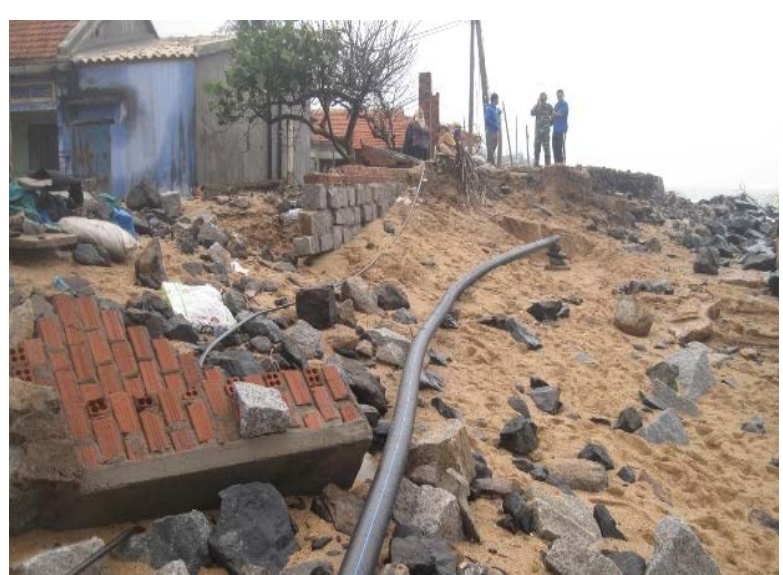

(b)

Hình 1. Một số hình ảnh về tác động của triều cuờng tại tại Cảng Cá-Tuy Hòa-Phú Yên: (a) Ngày 14/12/2016; (b) Ngày 16 tháng 12 năm 2018 [9]

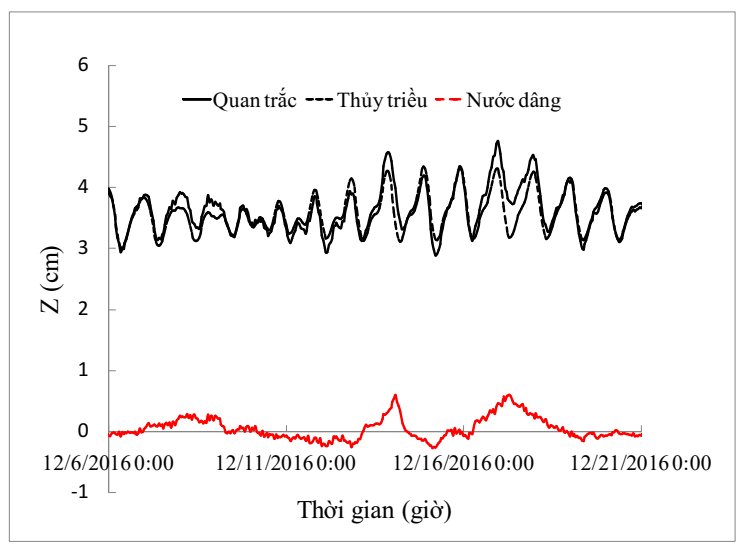

Hình 2. Biến thiên mực nước quan trắc, thủy triều và nước dâng tại trạm nghiệm triều ở cửa biển Tuy Hòa tháng 12/2016

\section{b) Phưong pháp nghiên cứu}

Nghiên cứu này sử dụng mô hình tích hợp 2 chiều SuWAT và để mô phỏng hiện tượng mực nước dâng dị thường trong đợt triều cường tháng 12 năm 2016 nhằm mục đích xác định nguyên nhân gây nước dâng dị thường tại khu vực.

SuWAT là mô hình tích hợp có thể tính riêng rẽ hoặc kết hợp cả thủy triều, sóng biển và nước dâng do bão/áp thấp nhiệt đới và gió mùa. Mô hình này được xây dựng tại đại học Kyoto - Nhật Bản [8], bao gồm 2 mô hình thành phần là mô hình thủy triều và nước dâng dựa trên hệ phương trình nước nông 2 chiều có tính đến nước dâng do ứng suất sóng và mô hình sóng SWAN. Mô hình SuWAT đã được nghiên cứu áp dụng tại Việt Nam trong mô phỏng thủy triều, sóng và nước dâng do bão trong một số nghiên cứu gần đây $[1,3]$. Kết quả kiểm định của các nghiên cứu này đã phản ánh khả năng của mô hình trong dự báo thủy triều, nước dâng do bão và sóng biển tại ven biển Việt Nam. Trong nghiên cứu này, việc áp dụng mô hình SuWAT nhằm đánh giá nước dâng gây bởi ứng suất gió và ứng suất sóng. Theo đó, nước dâng sẽ được mô phỏng theo 2 phương án, có và không xét tới ảnh hưởng của sóng. Nước dâng do ứng suất sóng rất có thể là đáng kể do trong thời gian này đã nhận có sóng lớn tại khu vực. Ngoài ra, với địa hình ven bờ dốc và trường sóng lớn duy trì trong thời gian dài sẽ là cơ chế thuận lợi gây nước dâng do sóng cao.

Dũ liệu địa hình được lấy từ GEBCO (Mỹ) độ phân giải 4 phút cho lưới tính Biển Đông và số liệu được số hóa từ bản đồ địa hình đáy biển 
tỉ lệ 1/100.000 của Tổng cục Biển và Hải đảo dùng cho lưới khu vực (D2) và địa phương (D3).

\section{Kết quả mô phỏng}

Mô hình SuWAT được thiết kế lưới tính lồng 3 lớp (Hình 3). Trong đó, lưới tính Biển Đông (lưới $\mathrm{D} 1$ ) là miền tính lớn nhất với độ phân giải ngang 4 phút (khoảng $7.400 \mathrm{~m}$ ), bao phủ từ vĩ độ $5^{\circ}-25^{\circ} \mathrm{N}$, kinh độ $103^{\circ}-120^{\circ} \mathrm{E}$. Lưới lồng kế tiếp (lưới $\mathrm{D} 2$ ) bao trùm toàn bộ ven biển miền Trung với miền tính $6.0^{\circ}-11^{\circ} \mathrm{N}, 108.0^{\circ}-112^{\circ} \mathrm{E}$ với độ phân giải khoảng $1.000 \mathrm{~m}$. Lưới lồng thứ 3 (D3) trong pham vi $12.5^{\circ}-13.75^{\circ} \mathrm{N}, 109.0^{\circ}-$ $109.5^{\circ} \mathrm{E}$ với độ phân giải khoảng $300 \mathrm{~m}$ bao trùm hết ven biển Tuy Hòa.

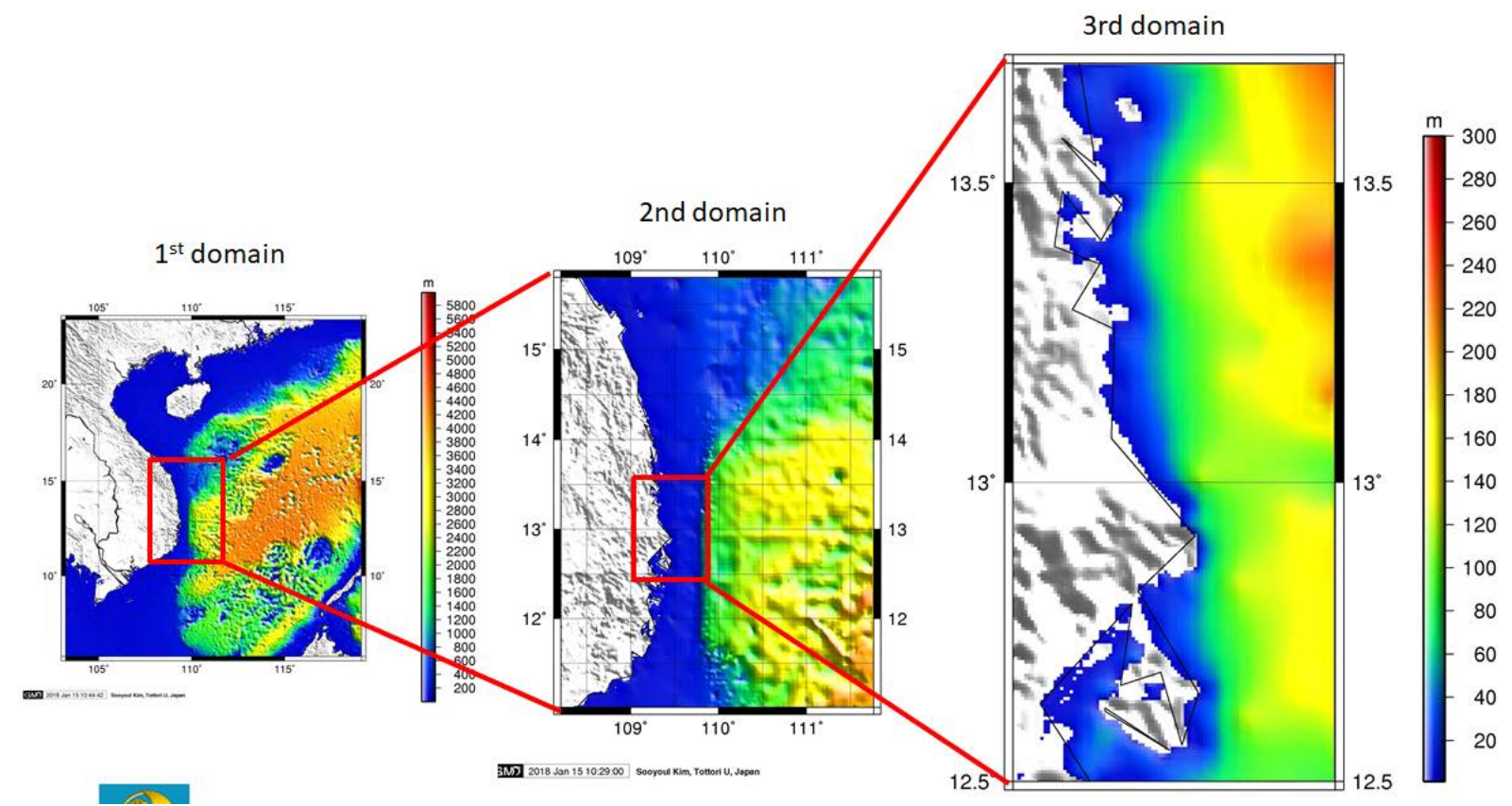

Hình 3. Miền tính và trưòng độ sâu cho mô hình SuWAT tại ven biển miền Trung

Trường gió và khí áp làm đầu vào cho mô hình SuWAT trong khoảng thời gian trước và sau khi xuất hiện nước dâng dị thường (từ 10/1218/12/2016) được mô phỏng chi tiết bằng mô hình WRF với độ phân giải $3 \mathrm{~km}$, bước thời gian trích xuất số liệu 15 phút. Mục đích của mô phỏng chi tiết trường gió và khí áp nhằm bắt được những hình thế ở quy mô nhỏ, rất có thể quy mô này là nguyên nhân gây nước dâng dị thường tại khu vực. Kết quả mô phỏng trường gió và khí áp từ mô hình WRF cho thấy hình thế thời tiết bị chi phối bởi gió mùa Đông Bắc mạnh, lấn sâu xuống phía Nam và đồng thời tồn tại một vùng áp thấp ở ngoài khơi giữa Biển Đông và có hướng di chuyển vào ven bờ Nam Trung Bộ (Hình 4).

Mô hình SuWAT sử dụng 2 phương án tính nước dâng, đó là có và không xét tới ảnh hưởng của sóng. Đối với phương án xét tới ảnh hưởng của sóng, phân bố nước dâng lớn nhất trong thời đoạn tính toán thể hiện trên hình $5 \mathrm{a}$ cho thấy phạm vi nước dâng lớn không chỉ tập chung tại ven biển Tuy Hòa-Phú Yên mà còn trải dài lên phía Bắc và xuống phía Nam. Độ cao sóng có nghĩa lớn nhất trên hình $5 \mathrm{~b}$ cho thấy gió mùa Đông Bắc với cường độ mạnh gây sóng cao tới $3 \mathrm{~m}$ tại ven bờ Tuy Hòa. So sánh biến thiên nước dâng tính toán và quan trắc tại trạm nghiệm triều Tuy Hòa trên hình 6 cho thấy mô hình đã phản ánh được diễn biến xu thế nước dâng trong thời gian này, tức là đã ghi nhận được hai đỉnh nước dâng vào đêm ngày 14 và 16 tháng 12 , nhưng kết quả thiên thấp so với thực tế $(0,35 \mathrm{~m}$, thực tế $0,61 \mathrm{~m}$ vào 23 giờ ngày 16 tháng 12$)$. 


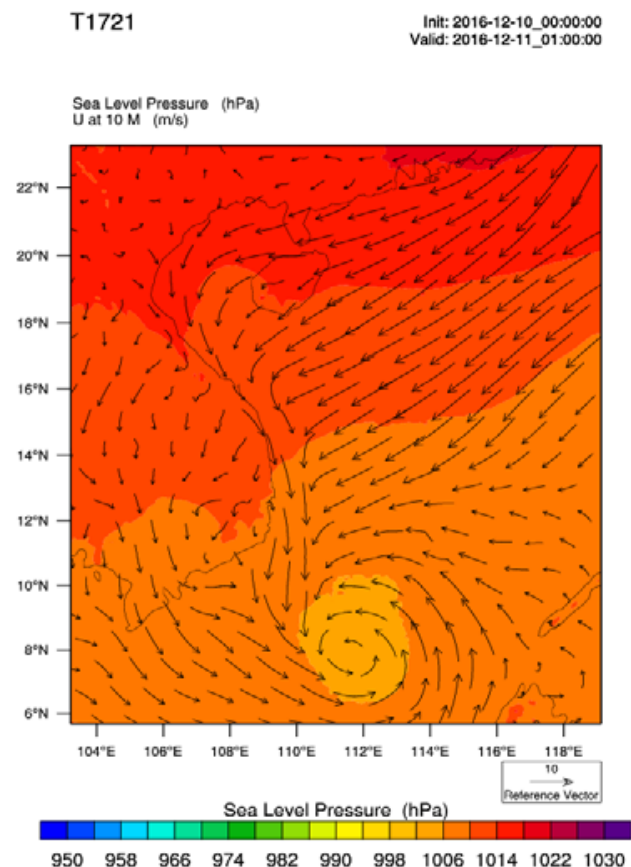

(a) 1 giờ ngày $11 / 12 / 2016$

Init: 2016-12-10_00:00:00
Valid: 2016-12-15-20:00:00

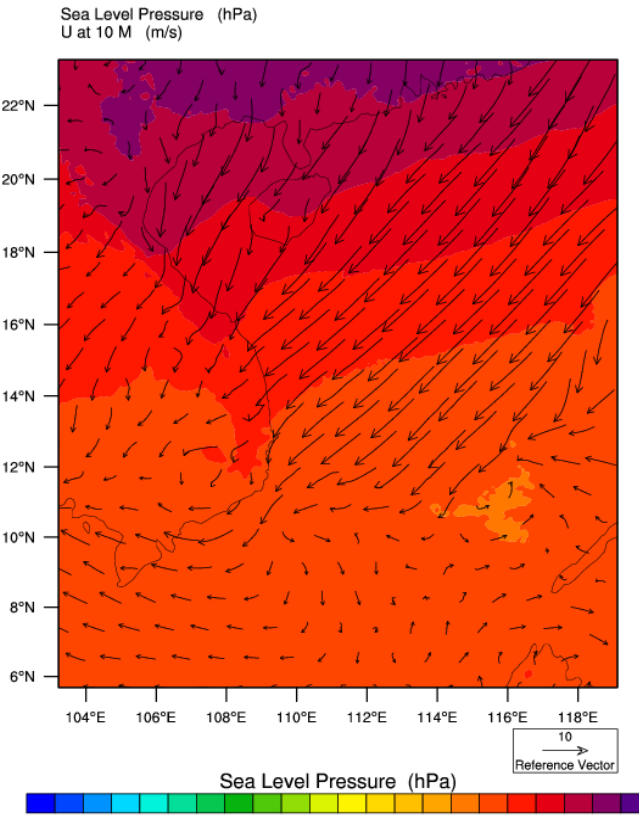

$\begin{array}{lllllllllll}950 & 958 & 966 & 974 & 982 & 990 & 998 & 1006 & 1014 & 1022 & 1030\end{array}$

(c) 20 giờ ngày 15/12/2016

T1721

Init: 2016-12-10_00:00:00
Valid: 2016-12-12_22:00:00

Sea Level Pressure (hPa)
Uat $10 \mathrm{M}(\mathrm{m} / \mathrm{s})$

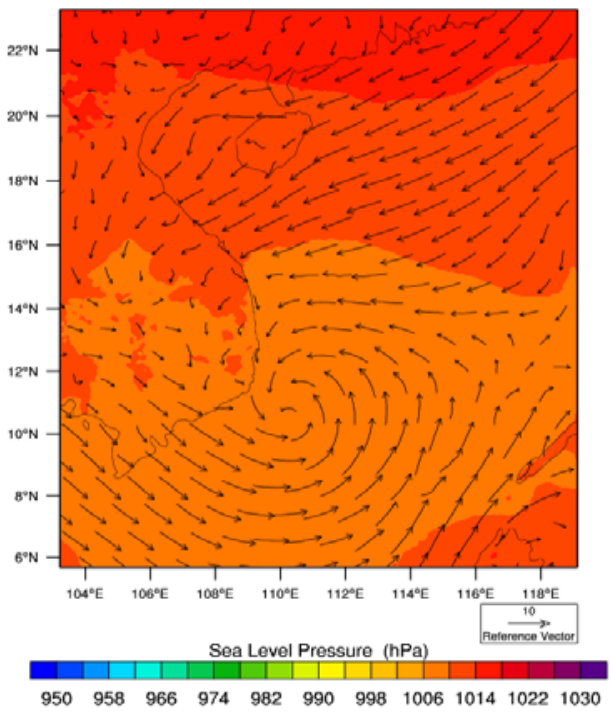

(b) 22 giờ ngày $12 / 12 / 2016$

T1721 Init: 2016-12-10_00:00:00
Valid: 2016-12-16_23:00:00

Sea Level Pressure (hPa)

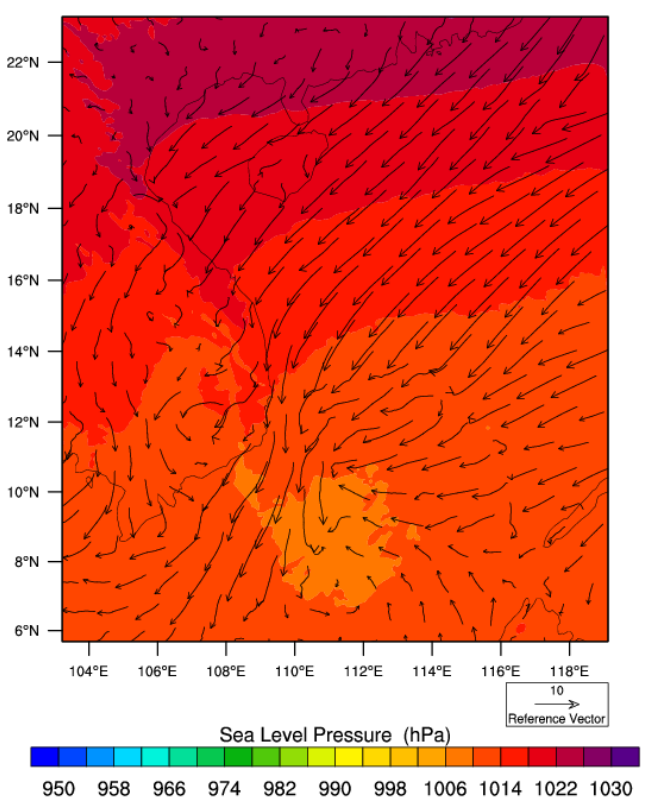

(d) 23 giờ ngày 16/12/2016

Hình 4. Truờng gió và khí áp trong đợt triều cường vào giữa tháng 12 năm 2016 


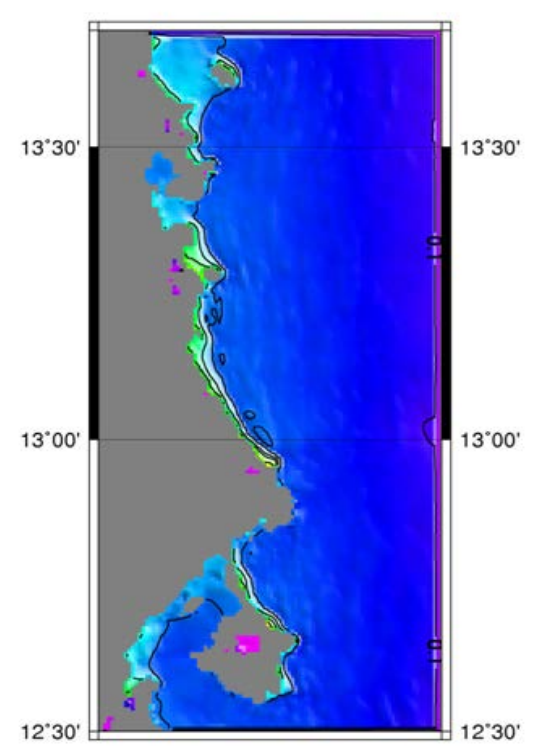

(a)

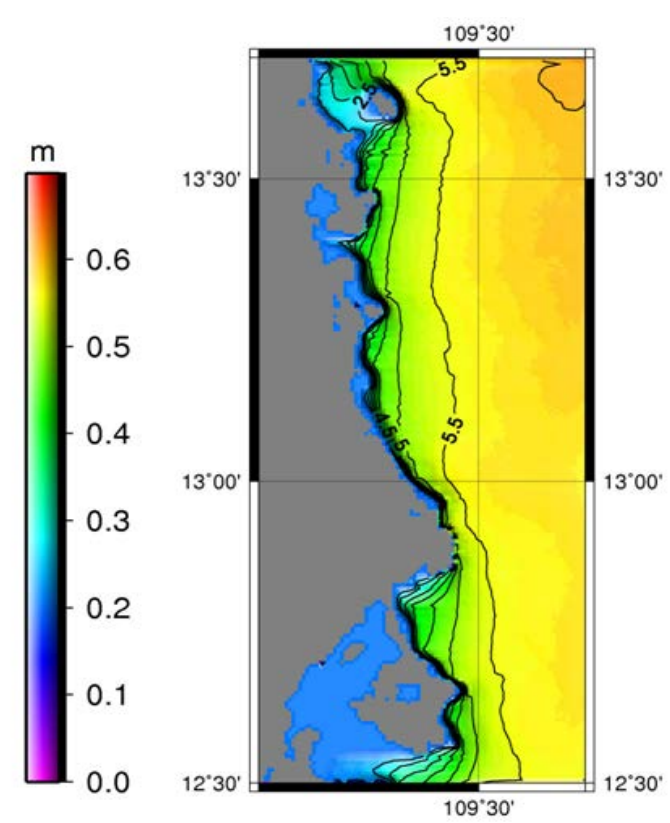

(b)

Hình 5. Phân bố nước dâng lớn nhất (a), độ cao sóng có nghĩa lớn nhất (b) trong đợt triều cương tháng 12 năm 2016

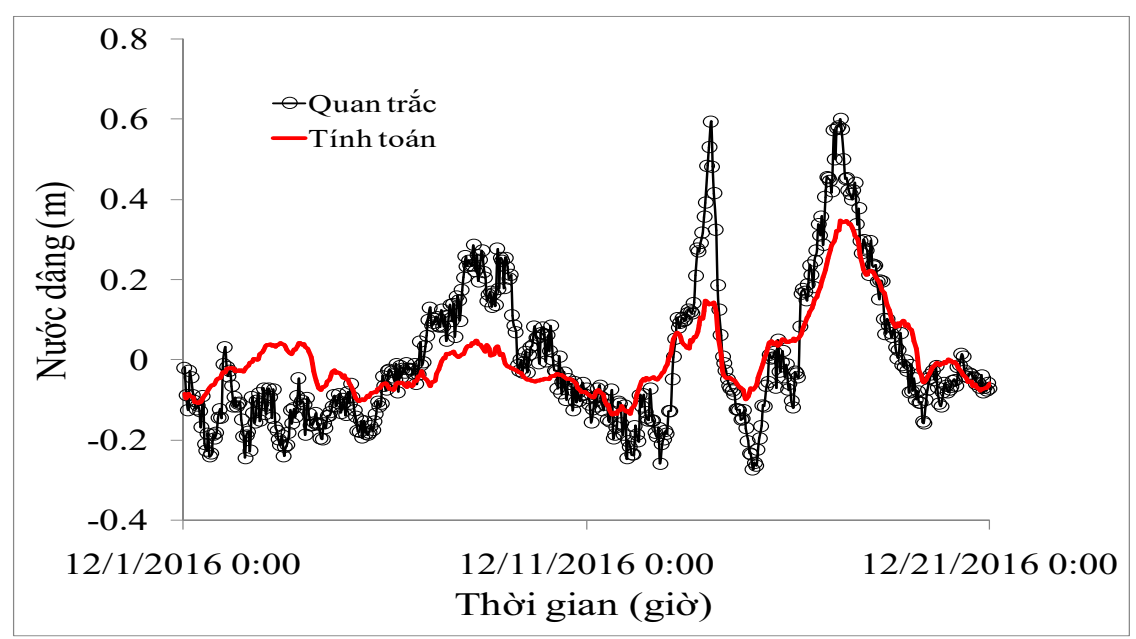

Hình 6. So sánh nước dâng tính toán và quan trắc trong đọt triều cuờng tháng 12 năm 2016 tại trạm quan trắc bổ sung Tuy Hòa

Trường sóng lớn do tác động của gió mùa Đông Bắc có cường độ mạnh có thể làm ra tăng mực nước dâng tại vùng ven bờ thông qua ứng suất bức xạ sóng, nhất là tại khu vực có địa hình dốc như ven biển miền Trung. Do vậy, để đánh giá ảnh hưởng của nước dâng do ứng suất sóng gây nên, phương án tính nước dâng không xét tới ảnh hưởng của sóng được thực hiện. Kết quả so sánh biến thiên nước dâng giữa 2 phương án tính, có và không xét tới ảnh hưởng của sóng trên hình 7 cho thấy nước dâng do ứng suất sóng chiếm tỷ lệ đáng kể, nhất là tại đỉnh nước dâng (khoảng $0,11 \mathrm{~m}(32 \%)$ tại thời điểm 23 giờ ngày 16 tháng 12). Qua đây cho thấy, sóng lớn và địa hình vùng bờ dốc góp phần gây nước dâng trong đợt triều cường này. 


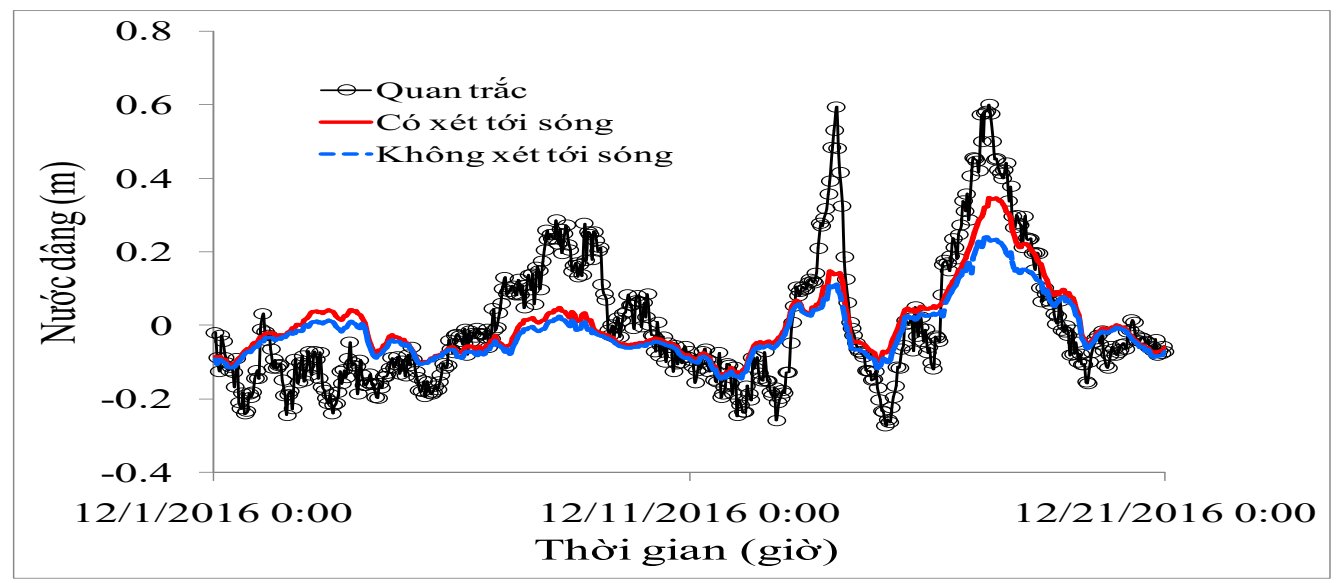

Hình 7. So sánh nước dâng tính toán và quan trắc trong đợt triều cuờng tháng 12 năm 2016 tại trạm quan trắc bổ sung Tuy Hòa

\section{Kết luận}

Trong nghiên cứu này, hiện tượng nước dâng dị thường trong đợt triều cường vào tháng 12 năm 2016 được mô phỏng bằng mô hình số trị tích hợp SuWAT nhằm đánh giá vai trò của ứng suất gió và ứng suất sóng tới tới dâng. Trường gió và khí áp làm đầu vào cho mô phỏng nước dâng được tính từ mô hình WRF. Kết quả cho thấy mô hình mô phỏng tương đối tốt diễn biến nước dâng trong đợt triều cường này nhưng thiên thấp so với thực tế. Hiện tượng nước dâng dị thường trong đợt triều cường tháng 12 năm 2016 ngoài tác động trực tiếp của ứng suất gió lên bề mặt biển thì nước dâng do ứng suất sóng cũng chiếm một phần đáng kể. Nước dâng do sóng cao bởi trường gió Đông Bắc mạnh gây sóng lớn tại vùng ven biển có độ dốc lớn. Để có thể mô phỏng đầy đủ định lượng hiện tượng nước dâng dị thường tại khu vực cần xem xét tới các hiệu ứng gây nước dâng khác như bơm Ekman, ngoài ra cũng cần thiết phải xây dựng lưới tính của mô hình khí tượng và hải dương với độ phân giải cao hơn, đây cũng là các nội dung nghiên cứu trong thời gian tới. Kết quả của nghiên cứu có ý nghĩa cho xây dựng công nghệ cảnh báo, dự báo hiện tượng nước dâng dị thường tại khu vực.

Lời cảm ơn: Nghiên cúu này được tài trợ bởi Quỹ Phát triển khoa học và công nghệ Quốc gia (NAFOSTED) trong đề tài mã số 105.06-2017.07). Tác giả xin chân thành cảm ơn.

\section{Tài liệu tham khảo}

1. Đỗ Đình Chiến, Nguyễn Bá Thủy, Nguyễn Thọ Sáo, Trần Hồng Thái, Sooyoul Kim (2014), Nghiên cứu tương tác sóng và nước dâng do bão bằng mô hình số trị, Tạp chí Khí tượng Thủy văn, (647), tr.19-24.

2. Trần Hồng Thái, Trần Quang Tiến, Nguyễn Bá Thủy, Dương Quốc Hùng (2017), Hiện tương mực nước biển dâng dị thường tại Tuy Hòa - Phú Yên. Tạp chí khí tượng thủy văn, số 676 trang 19.

3. Nguyễn Bá Thủy, JHoàng Đức Cường, Dư Đức Tiến, Đỗ Đình Chiến, Sooyoul Kim (2014), Đánh giá diễn biến nước biển dâng do bão số 3 năm 2014 và vấn đề dụ báo, Tạp chí Khí tượng Thủy văn, (647), tr.14-18.

4. Nguyễn Bá Thủy, Trần Quang Tiến (2018), Bước đầu nghiên cứu mối liên hệ giữa mực nước biển dâng dị thuoòng tại Tuy Hòa - Phú Yên với hình thế thời tiết. Tạp chí khí tượng thủy văn. Số 687 , trang 15-22.

5. Bertin, X.; Li, K.; Roland, A., and Bidlot, J.R. (2015), The contribution of short waves in storm 


\title{
BÀI BÁO KHOA HỌC
}

surges: two recent examples in the central part of the bay of Biscay. Continental Shelf Research 96, $1-15$.

6. Chen, W.B., Lin, L.Y., Jang, J.H. (2017), Simulation of typhoon-induced storm surge storm tides and wind waves for the Northeastern coast of Taiwan Using a tide-surge-wave couple model. Water research, Vol. 9, 549.

7. Funakoshi, Y., Hagen, S.C., Bacopoulos, P. (2008), Coupling of hydrodynamic and wave models: case study for Hurricane Floyd (1999) Hindcast, Journal of Waterway, Port, Coastal and Ocean Engineering, (134), pp. 321-335.

8. Kim, S.Y., Yasuda, T., Mase, H. (2010), Wave set-up in the storm surge along open coasts during Typhoon Anita. Coastal Engineering, Vol (57), pp. 631-642.

9. https://vov.vn/tin-24h/phu-yen-trieu-cuong-pha-huy-ke-xom-ro-578587.vov

\section{NUMERICAL SIMULATION THE ABNORMAL SURGE ON THE SPRING TIDE PHASES AT TUY HOA-PHU YEN INDECEMBER 2016}

\author{
Nguyen Ba Thuy ${ }^{1}$ \\ ${ }^{1}$ National Hydrometeorolocical Forecasting Center
}

\begin{abstract}
In this study, the abnormal surge during the spring tide phases at Tuy Hoa-Phu Yen in December 2016 was simulated by a coupled model of surge wave and tide (SuWAT). In particular, tide and storm surge are simulated by two dimensional long wave equations taking into account the wave radiation stress, obtained from the SWAN model. The SuWAT model is applied to simulate the surge induced by wind stress and wave radiation stress. The wind and pressures fields were simulated by WRF model. The results indicate that the model simulated well the tendency of surge althought it under estimated. The surge induced by wave contributes up to $32 \%$ to the total simulated surge.
\end{abstract}

Keywords: Abnormal surge, wind stress, wave setup, spring tide. 